\title{
Circ_000703 I Serves as a Sponge of miR-760 to Regulate the Growth and Chemoradiotherapy Resistance of Colorectal Cancer via Regulating DCP IA [Retraction]
}

\author{
Wang Y, Wang H, Zhang J, et al. Cancer Manag Res. \\ 2020;12:8465-8479.
}

The Editor-in-Chief and Publisher of Cancer Management and Research wish to retract the published article.

The journal was notified of potential data errors in the published paper. The authors were unable to provide satisfactory raw data for the western blots and the Editor determined the findings were no longer valid and requested for the paper to be retracted.

Our decision-making was informed by our policy on publishing ethics and integrity and the COPE guidelines on retraction.

The retracted article will remain online to maintain the scholarly record, but it will be digitally watermarked on each page as "Retracted".

\section{Publish your work in this journal}

Cancer Management and Research is an international, peer-reviewed open access journal focusing on cancer research and the optimal use of preventative and integrated treatment interventions to achieve improved outcomes, enhanced survival and quality of life for the cancer patient.
The manuscript management system is completely online and includes a very quick and fair peer-review system, which is all easy to use. Visit http://www.dovepress.com/testimonials.php to read real quotes from published authors. 